\section{Spontaneous \\ haemothorax \\ associated with von \\ Recklinghausen's \\ disease: review of \\ occurrence in Japan}

Hiroyuki Miura, Osamu Taira, Osamu Uchida, Jitsuo Usuda, Shigeru Hirai, Harubumi Kato

\begin{abstract}
The case history is presented of a 61 year old man with von Recklinghausen's disease who developed a spontaneous haemothorax. In spite of being asymptomatic for five days after drainage, he died as a result of fatal sudden re-bleeding. The post mortem examination showed dissection and rupture of the left subclavian artery. Microscopically, disarrangement of smooth muscle and decrease of elastic fibre was observed in the ruptured artery. Haemothorax in patients with von Recklinghausen's disease may require thoracotomy, even if the condition of the patient appears to be stable.
\end{abstract}

(Thorax 1997;52:577-578)

Keywords: haemothorax, von Recklinghausen's disease, neurofibromatosis.

Von Recklinghausen's disease is transmitted by an autosomal dominant gene and is characterised by multiple skin tumours and abnormal cutaneous pigmentation. Benign schwannomas, osseous system involvement, malignant schwannomas, other types of cancer, and central nervous system involvement are recognised associated complications. ${ }^{1}$ Vascular lesions are rare but sometimes fatal. ${ }^{2}$ We report a patient with von Recklinghausen's disease with haemothorax who was asymptomatic for five days after drainage but who died due to sudden re-bleeding. The cause of arterial rupture was different from those previously reported.

Center

Medical College,

Tokyo, Japan

Department of Surgery, Tokyo Medical College, Tokyo, Japan H Kato

Correspondence to: Dr H Miura.

Received 27 November 1995 Returned to authors 4 April 1996

Revised version received

24 June 1996

Accepted for publication

18 July 1996 department complaining of left shoulder pain and momentary loss of consciousness. He had suffered from hypertension and atrial fibrillation for 10 years. He had suffered a transient ischaemic attack at the age of 57 . Neurofibromatosis was diagnosed when he was aged 50 without known involvement other than cutaneous manifestations of the disease. There
A 61 year old man presented at our emergency

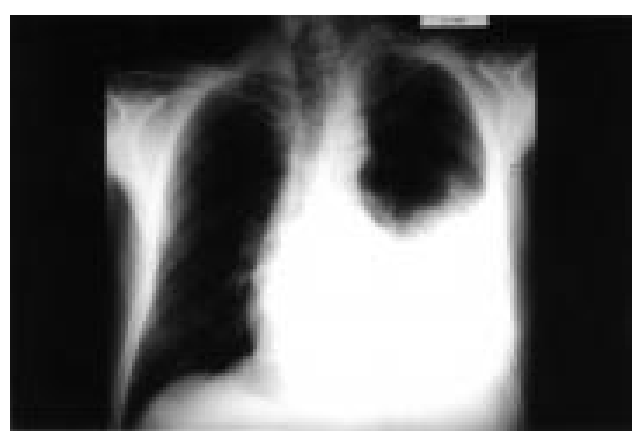

Figure 1 Chest radiograph on arrival showing a left pleural effusion.

was no history of trauma. A chest radiograph showed a left pleural effusion (fig 1). A plain computed tomographic (CT) scan showed a left pleural effusion with high density areas suspicious of blood. There was no evidence of an aneurysm. Numerous subcutaneous tumours were seen on the face, trunk, and limbs. There were no abnormal neurological findings although there was tachycardia $(170 / \mathrm{min})$ and the blood pressure was $120 /$ $80 \mathrm{~mm} \mathrm{Hg}$. Atrial fibrillation was observed on the ECG and the haemoglobin level was $11.2 \mathrm{~g} / \mathrm{dl}$.

An intercostal drainage tube was inserted and approximately $1000 \mathrm{ml}$ of blood was removed. After drainage the serous bloody discharge decreased to below $100 \mathrm{ml}$ per day. Radiologically there was no evidence of an increase in the pleural effusion.

Five days after admission he suddenly collapsed and his blood pressure was unrecordable. Although cardiopulmonary resuscitation was immediately performed, he died. Blood did not flow out from the chest drainage tube. The chest radiograph taken two hours before cardiac arrest also showed no increase in the pleural effusion.

The post mortem examination revealed about $4000 \mathrm{ml}$ of blood in the thoracic cavity. The tumorous lesion with haematoma, about $5 \mathrm{~cm}$ in diameter, in the apex was thought to have caused the dissection and rupture of the subclavian artery. Microscopically, disarrangement of smooth muscle and decrease of elastic fibres were observed in the ruptured artery. Proliferation of fibroblasts, indicating that the rupture had occurred several times, was observed at the ruptured portion. Neurofibromas were not seen at the ruptured portion.

\section{Discussion}

The incidence of vascular lesion in patients with von Recklinghausen's disease has been reported to be only $3.6 \%{ }^{1}$ Arterial lesions are classified into five types: ${ }^{34}$ (1) the pure intimal form, (2) the intimal-aneurysmal form, (3) the periarteriolar nodular form, (4) the advanced intimal form, and (5) the epithelioid form. These lesions involved small vessels less than $1 \mathrm{~mm}$ in diameter. Greene $e t a l^{5}$ investigated the arterial lesions associated with neurofibromatosis and described two categories in 
Table 1 Spontaneous haemothorax in patients with neurofibromatosis reported in fapan

\begin{tabular}{|c|c|c|c|c|c|c|c|}
\hline $\begin{array}{l}\text { Patient } \\
\text { no. }\end{array}$ & $\begin{array}{l}\text { Age } \\
\text { (years) }\end{array}$ & Sex & Location & Ruptured artery & Operation & Prognosis & $\begin{array}{l}\text { Neurofibromatous } \\
\text { invasion in } \\
\text { blood vessels }\end{array}$ \\
\hline 1 & 55 & $M$ & Right & Intercostal & Resection & Alive & + \\
\hline 2 & 43 & $\mathrm{~F}$ & Left & Internal thoracic & NP & Dead & $-* *$ \\
\hline 3 & 32 & $\mathrm{~F}$ & Right & Subclavian & Ligation & Dead & + \\
\hline 4 & 38 & $\mathrm{~F}$ & Left & Subclavian & Ligation & Alive & + \\
\hline 5 & 37 & $\mathrm{~F}$ & Left & Subclavian & Thoracotomy & Dead & $?$ \\
\hline 6 & 48 & $\mathrm{~F}$ & Left & Unknown & Thoracotomy & Dead & ? \\
\hline 7 & 31 & $\mathrm{~F}$ & Right & Intercostal & Ligation & Alive & ? \\
\hline 8 & 55 & $\mathrm{~F}$ & Left & Intercostal & $\begin{array}{l}\text { Resection and implantation } \\
\text { of descending aorta }\end{array}$ & Alive & + \\
\hline 9 & 53 & $M$ & Right & Innominate & $\begin{array}{l}\text { Resection and aorta- } \\
\text { innominate bypass }\end{array}$ & Dead & - \\
\hline 10 & 48 & $\mathrm{~F}$ & Left & Internal thoracic & Resection & Alive & ? \\
\hline 11 & 67 & $\mathrm{~F}$ & Left & Intercostal & Haemostasis & Alive & ? \\
\hline $12 *$ & 61 & $M$ & Left & Subclavian & $\mathrm{NP}$ & Dead & - \\
\hline
\end{tabular}

relation to the diameter of the vessels: the larger vessels such as the aorta, carotid, and proximal renal arteries which are surrounded by neurofibromatous or ganglioneuromatous tissue in which intimal proliferation, thinning of the media, and fragmentation of elastic tissue leading to stenosis or aneurysm formation may be found, and smaller vessels not related to neural malformation but showing a dysplasia of the vessel, classified into the aforementioned five types.

Two hypotheses for rupture of a major artery were proposed by Leier et $a .^{2}$ Firstly, the neurofibromatous invasion of the media may reduce the strength of the vessel wall and, secondly, tissue may compress the vasa vasorum of the large artery, resulting in a weakened segment of the artery secondary to ischaemia. Neurofibromatous proliferation was not observed in the vessel walls nor in the surrounding tissue in our patient, so rupture of the artery was not related to neurofibromatous invasion. Moreover, the pathological findings of our case did not differ from those previously reported. The disarrangement of smooth muscle and the decrease in elastic fibre were considered to be congenital malformations.

There have been only 12 spontaneous haemothoraces in patients with neurofibromatosis reported in Japan (table 1). The mean age of the patients was 47.3 years (range $31-67$ ), and they occurred more frequently in women and on the left side. The intercostal artery and the subclavian artery were the most common ruptured arteries. Pathological findings were described in seven of the 12 cases and there was a relationship between the vascular lesion and the neurofibroma in five of them. Neurofibromatous invasion of the vessel wall was observed in four and neurofibromatous tissue surrounding an artery causing ischaemic change of the artery occurred in one. The other cases, including the present one, showed no neurofibromatous proliferation. Surgery was performed in 10 patients. However, in two patients surgery ended in exploratory thoracotomy. Half of the patients, including the cases of exploratory thoracotomy, died due to blood loss. Among those undergoing thoracotomy there were cases in which the bleeding vessel was too fragile to suture so ligation, bypass, or replacement were chosen. The prognosis was poor in cases when the time from onset of bleeding to shock or loss of consciousness was short - that is, when the blood loss was massive. In the present case the time from onset of rebleeding to shock was too short for his life to be saved. As the blood pressure was maintained at the first rupture and a fair condition was maintained for five days, we should have had enough time to examine the ruptured artery. If patients with von Recklinghausen's disease who develop haemothorax are in shock, immediate thoracotomy is required. If angiography reveals the ruptured artery, embolisation should be undertaken to control the bleeding temporarily. However, urgent exploratory thoracotomy is needed in order to avoid re-bleeding even if the patient's condition appears to be stable.

The authors are indebted to Professor J Patrick Barron of The International Information Center of Tokyo Medical College for his review of the manuscript.

1 Brasfield RD, Gupta TKD. Von Recklinghausen's disease: a clinicopathological study. Ann Surg 1972;175:86-104.

2 Leier CV, Dewan CJ, Anatasia LF. Fatal hemorrhage as a complication of neurofibromatosis. Vasc Surg 1972;6: 98-101.

3 Reubi F. Les vaisseaux et les glandes endocrines dans la neurofibromatose: le syndrome sympathicotonique dans la maladie de Recklinghausen. Schweiz Z Pathol Bakterio 1944;7:168-236.

4 Feyter F. Uber die vasculare neurofibromatose, nach untersuchungen am menschlichen Magen-Darmschlauch. Vir chow's Arch Path Anat Physiol 1949;317:221-65.

5 Greene JF, Fitzwater JL, Burgess J. Arterial lesions associated with neurofibromatosis. Am f Clin Pathol 1974;62:41-7. 